\title{
EEN CHINESE BEELDBANK AAN DE HERENGRACHT IN DEN HAAG Jean Theodore Royers Chinese albums en schilderingen
}

'China' was voor veel Europeanen in de $17^{\mathrm{e}}$ en $18^{\mathrm{e}}$ eeuw een fascinerend onderwerp. Chinese producten, porselein, thee en zijde voorop, werden hoog gewaardeerd. Uit het grote aantal publicaties over dit verre keizerrijk in diezelfde eeuwen blijkt de aanhoudende belangstelling voor de Chinese 'zeden en gewoonten'.

Aan het einde van de $18^{e}$ eeuw ontstond, passend voor deze periode, onder sommige China-liefhebbers behoefte aan uitvoeriger informatie en ook aan uitgebreider beeldmateriaal. Het is dan ook niet verwonderlijk dat vanaf de jaren ' 70 albums naar Europa werden gebracht, waarin Chinese schilderingen over uiteenlopende onderwerpen waren samengebracht, zoals vissen, vlinders, bloemen en bloeiende struiken, maar ook de stadia van de productie van thee, zijde en porselein, de verschillende Chinese beroepen, en rangen en standen in de maatschappij. Een schildering werd op een stevig stuk papier geplakt en deze vellen (vaak 24) werden met stroken papier onderling verbonden tot een concertina. De buitenste platten werden bekleed met zijde en voorzien van een opschrift. Het album bestaat in China waarschijnlijk al vanaf de Noordelijke Song-tijd (960-1127), vooral om fragmenten van schilderingen of rubbings hanteerbaar te maken. Nieuw aan de albums die hier besproken worden, is dat zij speciaal voor de Europese kooplieden in Kanton werden gemaakt. Het behoort tot de exportkunst, kunst die speciaal voor Westerse kopers werd vervaardigd, soms - maar niet altijd - met gebruikmaking van Westerse voorbeelden, technieken, materialen en beeldconventies. De albums waren geen handelswaar voor de Europese compagnieën die in Kanton in deze jaren in de eerste plaats thee kochten, maar ze werden als aandenken of particuliere handelswaar door de opvarenden van de compagniesschepen meegenomen.

Het is bijzonder dat twee van de belangrijkste verzamelingen van deze albums door Nederlanders werden samengesteld. Beroemd is vooral de collectie van de VOC-koopman Andreas Everardus van Braam Houckgeest (1739-1801) die in de periode 1758-1795 viermaal in Kanton verbleef, de laatste keer als directeur van de factorij. Hij nam in 1795 deel aan de Nederlandse ambassade naar Peking, georganiseerd om de Qianlong-keizer te feliciteren met zijn 60-jarig regeringsjubileum. Dat betekende een reis door het binnenland van China en kennismaking met de hofrituelen, hetgeen hem in staat stelde om veel meer van China te zien en leren kennen dan de gewone Westerse handelaar die slechts in een klein afgeschermd gebied, net buiten de stad Kanton, mocht verblijven. Van Braam publiceerde een uitvoerig reisverslag waarin zijn grote collectie afbeeldingen uitvoerig wordt beschreven. ${ }^{1}$ De afbeeldingen, voor een deel gebaseerd op zijn eigen schetsen - ooggetuigenverslagen dus - speelden een belangrijke rol in Van Braams wens in

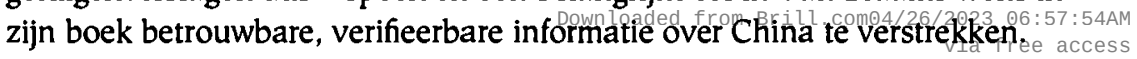


'Wat ik schrijf is waar, want $u$ kunt het op de afbeeldingen in mijn verzameling zien', was zijn gedachtegang. De lezer werd ook uitgenodigd de ongeveer 1800 bladen in zijn huis China Retreat, even buiten Philadelphia te komen bekijken. (Van Braam had zich na zijn laatste reis naar China in de Verenigde Staten gevestigd vanwege de onrustige situatie in Nederland in 1795.) Helaas heeft deze verzameling, waarvan over de totstandkoming en het doel veel bekend is, maar een paar jaar bestaan. Al in 1799 moest Van Braam, om een oplossing voor zijn acute geldnood te vinden, alles naar Londen verschepen en veilen bij Christie's, waarna de collectie verspreid is geraakt. De tweede Nederlandse collectie, bijeengebracht door Jean Theodore Royer (1737-1807) was gelukkig een beter lot beschoren: deze vond een plaats in het Koninklijk Kabinet van Zeldzaamheden, voorloper van het Rijksmuseum in Amsterdam en het Museum Volkenkunde in Leiden, de twee instellingen waar de collectie zich nog steeds bevindt. ${ }^{2}$ Voor Royer golden dezelfde idealen als voor Van Braam: betrouwbare informatie over China vergaren. Enerzijds probeerde hij de taal te leren om op die manier zelf Chinese bronnen te kunnen raadplegen, anderzijds legde hij een studieverzameling aan van Chinese voorwerpen die hem - zonder de tussenkomst van een auteur of wie dan ook - konden tonen hoe het leven in China eruit zag. Een kwestie is natuurlijk in hoeverre Royers schilderingen voor dit doel geschikt waren. Exportschilderingen waren ten dele aangepast aan de wensen en verwachtingen van de Europese kopers. Zoals echter uit het onderstaande zal blijken, behoorden niet alle schilderingen uit Royers collectie tot de categorie exportschilderingen en in sommige gevallen blijken ook exportschilderingen goede informatiebronnen voor Europese belangstellenden.

\section{Chinese schilderingen in de collectie Royer}

Royers collectie schilderingen is minder bekend dan die van Van Braam, maar was zelfs nog omvangrijker. De inventaris, gemaakt ten behoeve van overdracht aan het Kabinet van Zeldzaamheden in 1816, geeft het beste beeld van de veelzijdigheid - niet alle kwetsbare werken op papier zijn hun museumgeschiedenis ongeschonden doorgekomen en nu nog voorhanden. ${ }^{3}$ Het valt op dat de collectie schilderingen in verschillende media bevatte: de catalogus begint met schilderingen achter glas, dan volgen plaques van porselein en koper waarop voorstellingen in emailkleuren zijn geschilderd. Olieverf op doek, een geheel Westerse techniek die pas aan het eind van de $18^{\mathrm{e}}$ eeuw in Kanton was geïntroduceerd door de Europeanen, is ook vertegenwoordigd. Van de rolschilderingen met goden en mythologische wezens, in de inventaris met zorg gedetermineerd, is er nog maar één over. 'Leelijk' staat er in $19^{\mathrm{e}}$-eeuws handschrift op de buitenzijde van de rol, zodat de museummedewerkers niet langer de moeite hoefden te doen om te kijken wat er ook weer op stond. Wie op zoek is naar een voorbeeld van een Chinees schilderkunstig hoogtepunt, zal inderdaad teleurgesteld zijn in deze Guanyin met acolieten (afb. 1). Het is een afbeelding zoals er buitengewoon veel gemaakt zijn in China, bestemd voor privédevotie van eenvoudige mensen, zeker niet speciaal voor de Westerse kooplieden. Omdat dergelijke platen niet alleen in zeer groten getale werden vervaardigd, maar even massaal zijn weggegooid, is dit bewaard gebleven exemplaar wel degelijk van groot belang.

De collectie bevatte ook portefeuilles met losse prenten en tekeningen, onder andere van belangrijke gebouwen. Bij een van deze portefeuilles was het het 

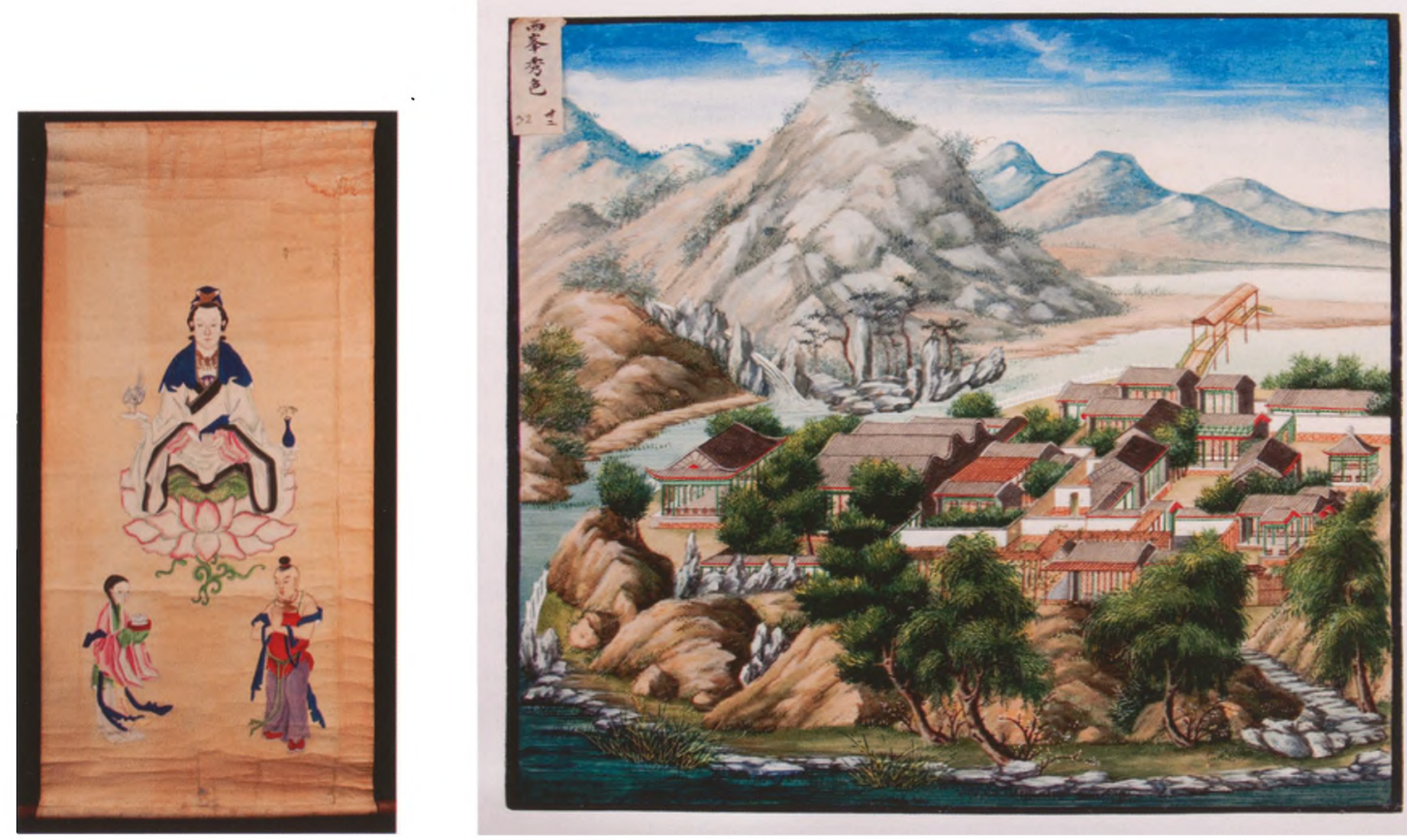

Afbeelding 1

Guanyin, waterverf op papier, hoogte $143 \mathrm{~cm}$, Museum Volkenkunde, 360-358

Afbeelding 2 Albumblad met het paviljoen Xifeng xiuse ('Elegant Color on the Western Peaks') in Yuanmingyuan, waterverf op papier, $35 \times 31 \mathrm{~cm}$, Museum Volkenkunde, 360 364hh precieze onderwerp op het moment dat de inventaris werd gemaakt, niet bekend. 'Voorname buitenplaatzen en Lusthoven door 't geheele Keizerrijk', is de omschrijving. ${ }^{4}$ Het is echter een bekende serie van veertig gezichten op de paviljoens in Yuanmingyuan, het Zomerpaleis van de keizers (afb. 2). ${ }^{5}$ De 40 schilderingen waren in 1744 voltooid en - voorzien van gedichten door Qianlong - tot twee albums gebonden. Haar bekendheid dankte de serie aan de gedrukte versies (houtsneden) waarvan de eerste in 1750 verscheen, waarna er nog verschillende volgden. Uit details blijkt dat Royers schilderingen zijn gebaseerd op een van deze houtsneden-edities. Ze moeten zijn vervaardigd door schilders die gewend waren voor de Westerse kopers te werken. De manier waarop volume wordt gesuggereerd door gebruik van chiaroscuro, en de toepassing van schaduwen - typerend voor de Europese schilderkunstige traditie en on-Chinees - wijzen daarop. Het is interessant dat in deze exportschilderingen wel de techniek, de manier van uitbeelden aan de wensen van de Europese kopers is aangepast, maar de onderwerpkeuze niet. Het was een onder Chinese kopers populaire serie. Dat Royer ook schilderingen bezat die niet tot de exportkunst gerekend kunnen worden, bleek al uit de rolschildering van Guanyin. Een ander voorbeeld maakt onderdeel uit van een charmante verpakking van vier soorten thee in de vorm van een rolschildering. Het landschap is een commerciële versie en late navolging van de literaten-landschapschilderstijl uit de Ming-tijd (afb. 3). ${ }^{6}$ De levensstijl van de Chinese culturele elite met de kunstvoorwerpen die daarin een rol speelden, werd in de $17^{\mathrm{e}}$ en $18^{\mathrm{e}}$ eeuw door veel Chinezen - ook al hoorden ze zelf helemaal niet tot die elite - als voorbeeld gezien en navolgingen als deze 'theerollen' staan zeker niet op zichzelf. Royer had dus een voorbeeld van door de keizer bestelde ${ }_{\text {via }}$ free access 
voorwoord vermeldt Mason dat hij de voorbeelden voor de gravures tien jaar eerder, dus in 1790, in Kanton had gekocht en het is bekend dat hij in dat jaar inderdaad in Kanton is geweest. Waar deze voorbeelden zich nu bevinden, staat niet vast. In het Victoria $\mathbf{B}$ Albert Museum bevindt zich een set van 100 bladen waarvan een groot deel exact met de gravures in het boek van Mason overeenkomt. De kwaliteit van de schilderingen is zeer goed en de Engelse watermerken bevestigen een datering rond 1790. Een serie in de Phillips Library in Salem (Mass.) van oorspronkelijk ten minste 95 bladen is dankzij een inscriptie te dateren als gemaakt in $1786 .{ }^{9}$ Wellicht had rond deze tijd het album met beroepen zich tot deze omvang en samenstelling ontwikkeld. ${ }^{10}$ Royers album is weliswaar gelijksoortig, maar bevat geen enkele afbeelding die met de Mason-gravures overeenkomt. Bovendien is Royers album veel uitgebreider. Het is een set van 12 albums, ieder met 24 bladen, in totaal dus 288 bladen. De beroepen zijn ver in de meerderheid, acht albums zijn hier grotendeels aan gewijd, maar daarnaast bevatten andere delen - vermengd met de 'beroepen' - afbeeldingen van Chinezen uit verschillende regio's van China en historische en mythologische figuren (afb. 5-8). In de collecties van Van Braam Houckgeest en de Indian Office Library worden deze onderwerpen - mythologische figuren en Chinezen uit verschillende regio's - ook genoemd, maar dan als afzonderlijke albums. ${ }^{11}$ Op grond van

Afbeelding 4

Boer bij een os, waterverf op papier, 174 $\times 126 \mathrm{~cm}$, Museum Volkenkunde, $360-368$

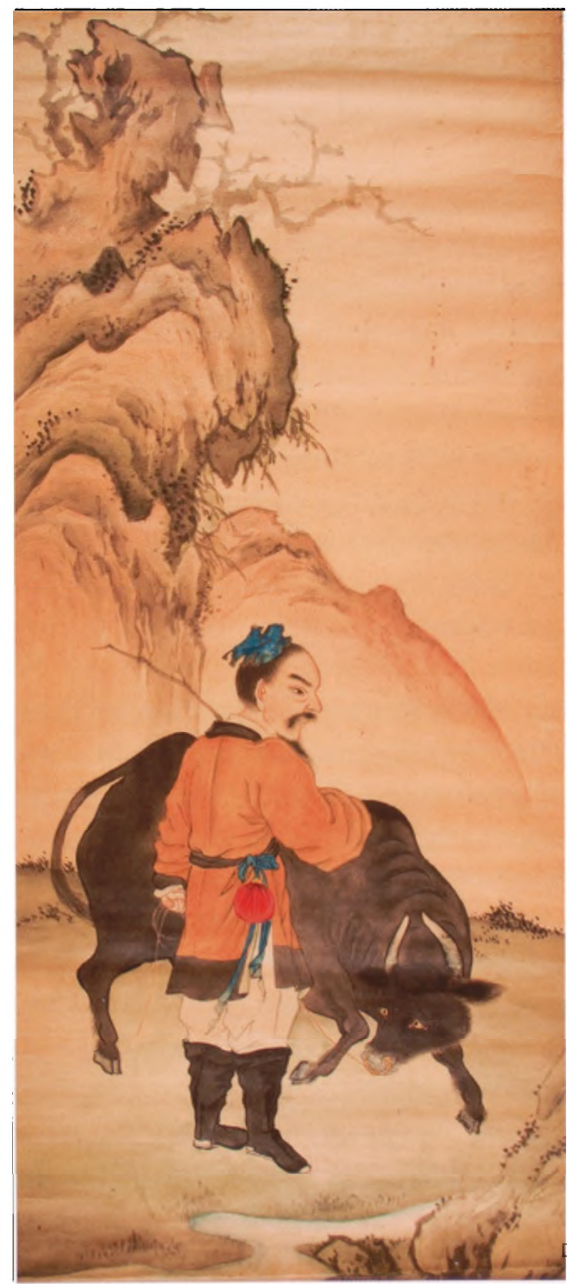


Afbeelding 5

Schoenmaker, blad uit een album met

allerhande Chinezen, waterverf op papier,
$29,9 \times 34,2 \mathrm{~cm}$

(schildering) $34 \times 37$

(album), Museum

Volkenkunde, 360-378 j
Afbeelding 6

Schilderingenverkoper,

blad uit hetzelfde album

als afb. 5, 360-378h

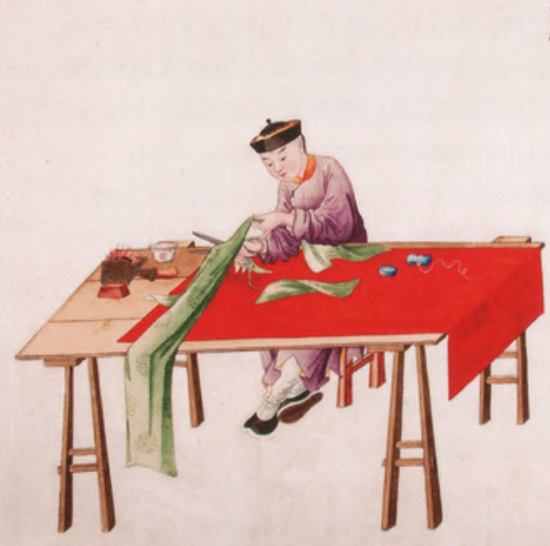

戴 Jow
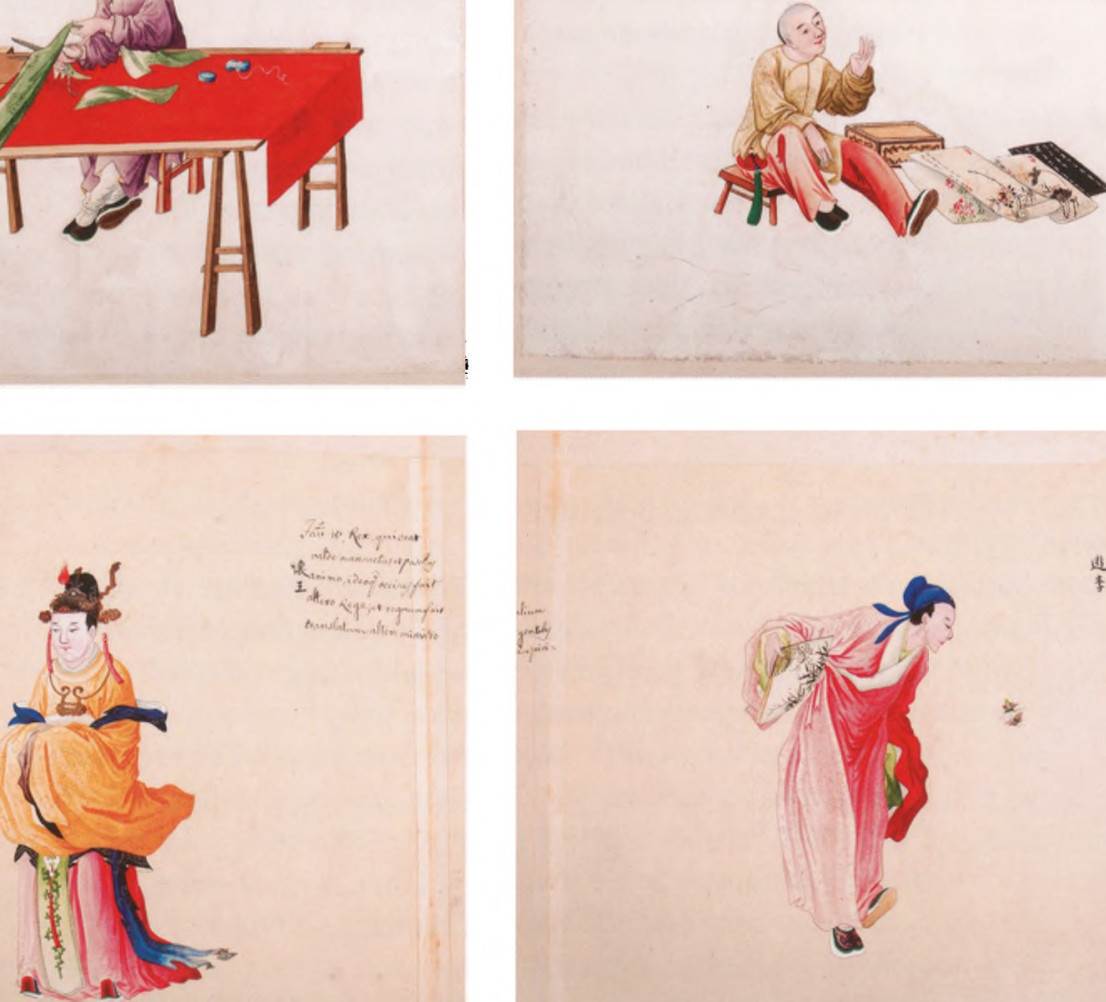

Afbeelding 8

Literaat, blad uit

hetzelfde album als afb.

5, 360-378d. De Latijnse

inscriptie: 'Een man

zonder publieke functie,

hoewel geleerd'

zelfde album als afb. 5 .

360-378b. De vertaling

van het Latijnse

bijschrift luidt: 'Huai

Wang, de koning die

heel vreedzaam en

bekrompen van geest

was en daarom ook

gedood is door de

andere koning [Xiang

Yul; en de regering is 
inscripties op de bladen van Royers albums bestaat het vermoeden dat ze aan de hierboven aan Puqua toegeschreven albums vooraf gaan. Bij het Chinees is een vertaling en soms een toelichting in het Latijn geschreven. Het handschrift is te herkennen als dat van de Chinees Carolus Wang. Deze Wang was een kleine handelaar en scharrelaar die enige jaren een priesteropleiding in Napels had genoten en daardoor uitstekend Latijn beheerste. ${ }^{12}$ Royer was met hem in contact gebracht door de VOC-koopman Ulrich Gualtherus Hemmingson (1741-1799) en uit bewaard gebleven brieven blijkt dat Wang Royer hielp bij zijn poging Chinees te leren lezen en bij het verzamelen van voorwerpen voor zijn collectie. Aangezien deze brieven alle dateren uit de periode 1773-1776, lijkt het aannemelijk dat de albums met Wangs inscripties ook in deze periode zijn vervaardigd en naar Royer verzonden. Daarmee zouden ze tot de vroegst bekende albums behoren.

Als Royers albums uit de jaren '70 van de $18^{\mathrm{e}}$ eeuw inderdaad tot de vroegste Chinese exportalbums behoren, dringen twee vragen zich op. In de eerste plaats, waarom ontstond dit genre zo laat? In porselein en beelden van ongebakken klei werd in China al decennia lang exact naar de Europese wensen gewerkt. In de tweede plaats is het van belang vast te stellen of de albums in onderwerpskeuze en uitvoering volledig Europees zijn of toch tot op zekere hoogte in een Chinese traditie staan. Eerst enkele observaties over de ontstaansgeschiedenis van Chinese exportschilderkunst op papier.

\section{Chinese exportschilderingen}

In de $16^{\mathrm{e}}$ en $17^{\mathrm{e}}$ eeuw bereikten Chinese schilderingen sporadisch Europese collecties. ${ }^{13}$ Van exportschilderingen is dan echter geen sprake. Het zijn 'gewoon' Chinese schilderingen bedoeld voor een Chinees publiek, maar als curiositeit meegenomen naar Europa. ${ }^{14}$

Opvallend genoeg is bij vroege vermeldingen van Chinese schilderingen die naar Europa worden verscheept, meestal sprake van schilderingen op glas. Uit de VOC-dagregisters in Kanton uit 1738 is de aankoop bekend van 24 glasschilderingen van de schilder Quoqua, 18 met verlakte lijsten en 6 met lijsten van rozenhout. ${ }^{15}$ William Chambers, auteur van Design of Chinese buildings, furniture, dresses, machines and utensils (Londen, 1757) bezocht Kanton in 1743 en 1748 . Hij ontmoette daar 'Siou Sing Saang', 'a celebrated Chinese master - I employed to paint on glass all Chinese dresses. ${ }^{16}$ Wat het onderwerp betreft (Chinese klederdrachten), lopen deze glasschilderingen vooruit op de latere albums met Chinezen in hun passende kleding. Schilderingen op papier lijkt voor het onderwerp meer voor de hand te liggen, maar blijkbaar was in deze periode achterglasschilderkunst een bekend en gewaardeerd exportproduct, maar schilderingen op papier nog niet. Een enkel album uit deze periode is bekend. Het bevat leden van de keizerlijke familie, en ook Chinezen die uiteenlopende beroepen uitoefenen. Aangezien het uit het bezit stamt van een Engelse supercargo die in 1735 in Kanton actief was, wordt het in die periode gedateerd. Dit album lijkt echter op zich zelf te staan. ${ }^{17}$ Het vroegste hierop volgende in de literatuur vermelde album stamt pas uit $1776 .{ }^{18}$ Onderzoek in 40 Nederlandse boedelbeschrijvingen en veilingcatalogi van collecties Chinese voorwerpen, bevestigt dit beeld. Allerhande Chinese voorwerpen komen voor, maar schilderingen nauwelijks en albums hoogst zelden. ${ }^{19}$ Alleen in de beschrijving van de enorme winkelvoorraad van Chinees porselein en andere Chinese kunstnijverheid: 
voorwerpen van Martha Raap uit 1778 komen ' 3 Boeken met fraaye oostindische Zeebomen' voor. ${ }^{20}$ In enkele gevallen worden in deze inventarissen en boedelbeschrijvingen wel groepen Chinees behangselpapier genoemd. Jan Rijke, wiens grote verzameling Chinese voorwerpen in 1786 werd geveild, bezat zelfs ensembles behangselpapier voor verschillende kamers. ${ }^{21}$ Op de beschrijvingen van kamerbehangsels volgde een groep van maar liefst 116 vellen van circa 1 bij 1,5 meter met voorstellingen (figuren in een landschap) die zeer vergelijkbaar waren met de kamerbehangsels. De indruk ontstaat dat zij ook in techniek en materiaal met deze behangsels overeenkwamen en alleen in formaat daarvan verschilden. In dit nieuwe formaat vormden zij een soort losse schilderijen. Bij recent onderzoek door Michael North naar het kunstbezit van inwoners in Batavia en aan de Kaap, is naar voren gekomen dat Chinese schilderijen daar juist rond het midden van de $18^{\mathbf{e}}$ eeuw plotseling in groten getale in de boedelbeschrijvingen beginnen voor te komen. Wat met de omschrijving 'Chinees schilderijtje' bedoeld kan zijn, is niet met zekerheid te zeggen, maar de meest voor de hand liggende verklaring op dit moment is dat het aan de productie van behangpapier verwante schilderingen zijn, zoals ook zo overvloedig bij Rijke beschreven. ${ }^{22}$ De schilderingen waren - zo blijkt uit de boedels die North onderzocht - laag in prijs, wat kopers met een krappe beurs in staat stelde toch de mode van de locale (Nederlandse) elite te volgen om kamers met schilderijen te decoreren. Deze Chinese schilderijen in het interieur waren in Azië veel algemener dan in Nederland.

De stap van losse schilderingen naar in een album gebonden bladen is maar klein en Friederike Wappenschmidt heeft in haar boek over Chinees behangpapier uit 1989 al gewezen op de overeenkomst tussen de albumschilderingen en behangselpapier. ${ }^{23} \mathrm{Zij}$ plaatst het werk van de Chinese exportschilders in een wat groter geheel en veronderstelt dat in Kanton in de $18^{e}$ eeuw beroepsschilders in grote ateliers werkten voor een vrij uiteenlopende clientèle en met een breed assortiment. ${ }^{24}$ Eenvoudige schilderingen voor Chinese kopers zoals de Guanyin en de man met de os, kunnen hier naast beschilderde behangsels op papier en zijde, losse vellen en albumbladen voor Europeanen gemaakt zijn. De productie van beschilderde behangsels voor de Europeanen begint al rond 1700. In Versailles komt in een beschrijving $1667 / 1669$ een vermelding in de garde meubles voor van schermen 'de la Chine peintes sur du papier'. ${ }^{25}$ Rond 1700 begint de aanvoer van Chinees behangselpapier door de Engelse Oostindische Compagnie en ook het eerste Franse schip dat in Kanton handelde, de Amphitrite, keerde in 1700 terug naar Frankrijk met beschilderd papier, geschikt voor wandbespanningen. ${ }^{26}$ Uit Wappenschmidts onderzoek in krantenadvertenties en archivalia blijkt dat Chinees behangselpapier in Europa tot circa 1760 een tamelijke bijzonderheid is en daarna volop verkrijgbaar. ${ }^{27}$ Omdat het voornamelijk particuliere handelswaar is, is informatie uit het VOC-archief over dit onderwerp schaars. Twee VOC-opdrachten zijn echter bekend, uit 1753 en uit $1786-1788 .{ }^{28} \mathrm{Bij}$ deze laatste opdracht worden de namen van schilders genoemd: Anthonij die al vanaf midden van de eeuw beschilderde zijde aan de VOC leverde, zorgde nu voor de ontwerpen van het behangpapier en voor een deel van de uitvoering. Het overige werd gemaakt door de schilder Seequa. Het was een grote opdracht en het werk moest in korte tijd worden uitgevoerd. Dat geeft aan dat deze ateliers van Anthonij en Seequa een grote capaciteit hadden. Rond $\mathbf{1 7 6 0}$ waren de ateliers geheel op stoom en in staat aan de Europese vraag naar geschilderd behang en kleinere formaten ${ }^{B}$ fre 

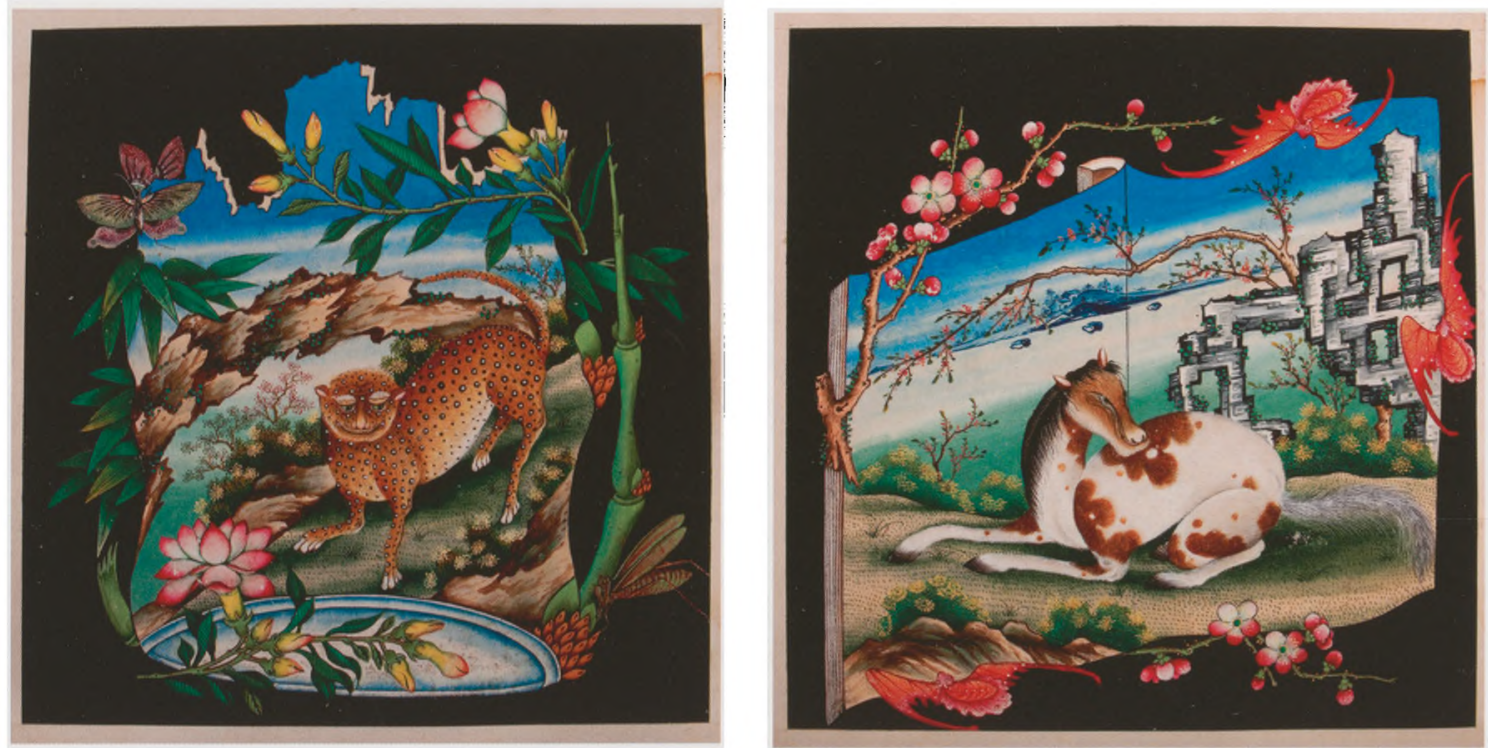

Afbeelding 9

Luipaard (?) in een cartouche in de vorm van een afgebroken stuk hout, blad uit een album met dieren en fabeldieren in cartouches tegen een zwarte achtergrond, waterverf op papier, 29,9 $\times 29 \mathrm{~cm}$ (schildering), $34 \times 32 \mathrm{~cm}$ (album), Museum Volkenkunde, 360-376

\section{Afbeelding 10} Paard in een cartouche in de vorm van een opengeslagen boek, uit hetzelfde album als afb. 9, Museum Volkenkunde, $360-376$ schilderingen te voldoen. Dat er in Europa vraag ontstond naar reeksen schilderingen over bepaalde onderwerpen, kwam de ateliers uitstekend uit. Buiten het seizoen kon voor eigen risico een voorraad albumbladen worden gemaakt die het volgende seizoen naar wens van de Europese kopers konden worden samengesteld en gebonden. De bladen in Royers set albums zijn, net als het behangpapier uit die tijd, geschilderd op Chinees papier. Verondersteld is wel dat vroege albums op uit Europa geïmporteerd papier (dat hoger werd gewaardeerd) zijn geschilderd. ${ }^{29}$ Met vroege albums worden echter de Puquasets uit circa 1790 bedoeld. Het lijkt me niet onwaarschijnlijk dat de albums toen al een goede reputatie hadden verdiend en dat juist daarom in die periode Europees papier werd geïntroduceerd. ${ }^{30}$ De late verschijning van de albumbladen laat zich dus verklaren door de veranderende wensen van de Europeanen en door de zich ontwikkelende mogelijkheden van de Chinese ateliers in het derde kwart van de $18^{\mathrm{e}}$ eeuw.

Albumbladen die primair decoratief zijn en niet zozeer een rol speelden als informatiebron over het dagelijks Chinese leven, bevestigen de band tussen albumbladen en behangpapier. De bladen uit een uiterst curieus album uit Royers verzameling met gewone dieren en fabeldieren in een cartouche, omgeven door bloemranken en daarbuiten een zwarte achtergrond, zijn daar een voorbeeld van (afb. 9, 10). Het werken met cartouches komt in verschillende vormen van Chinese kunstnijverheid voor, zoals de decoraties van porselein (afb. 11). Ook in boekillustraties wordt het soms toegepast, het meest voorkomend zijn 'gedachte-' of 'droomwolken' die soms de hele pagina in beslag nemen. ${ }^{31}$ Vroeg $20^{\mathrm{e}}$-eeuwse portretfoto's zijn soms in diezelfde vorm geknipt en tegen een witte achtergrond geplakt - blijkbaar bleef het gebruik van dergelijke cartouches geliefd. ${ }^{32}$ Een speciale categorie vormen de cartouches in de vorm van een scherm, rolschildering, of opengeslagen boek, zoals ook op het afgebeelde albumblad van Royer. Er ontstaat dan een spel van een 'beeld in een beeld'. Ook dit principe is uit $17^{\mathrm{c}}$-eeuwse boekillustraties bekend. Er is op gewezen dat boeken met dergelijke illustraties voor een

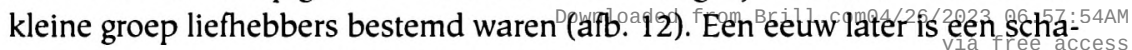



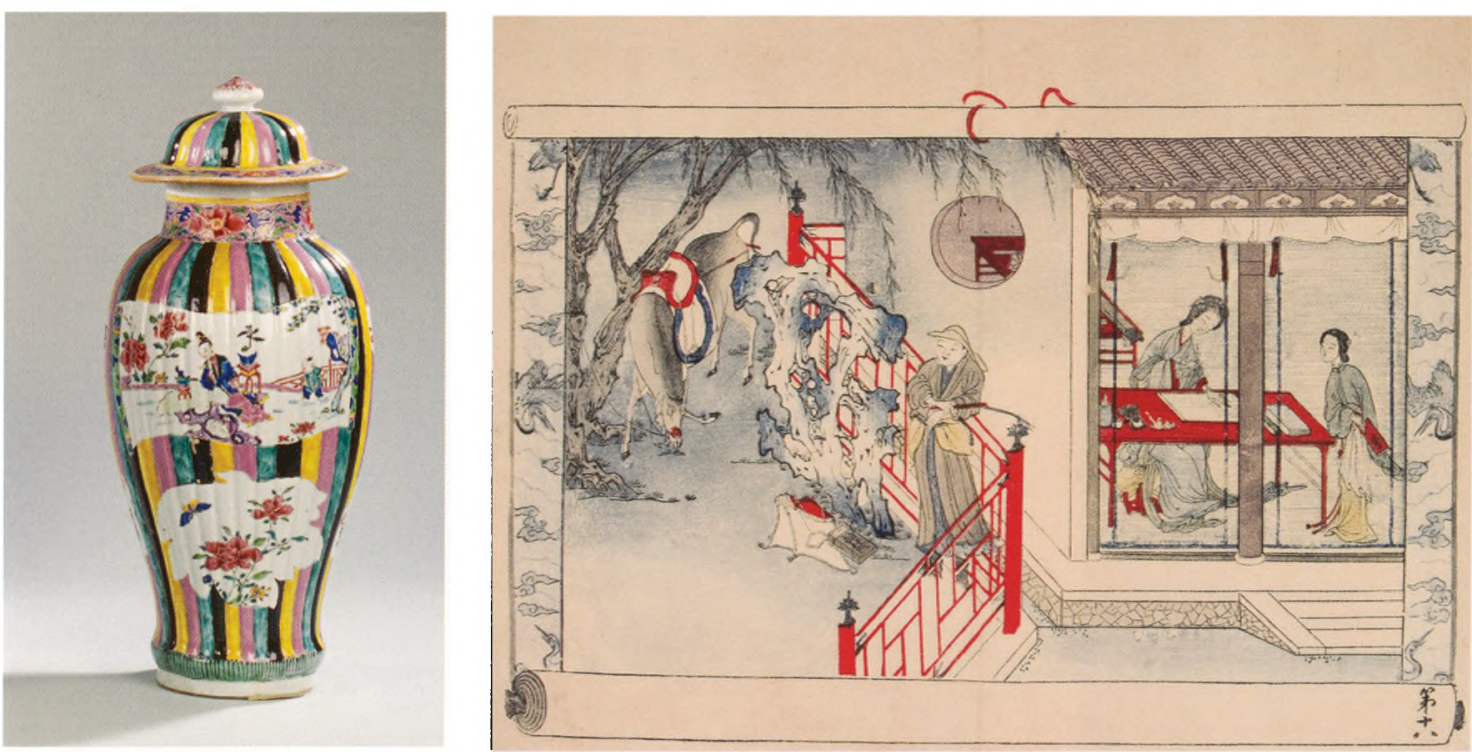

Afbeelding 11

Dekselpot uit een kaststel, porselein met emailkleuren, hoogte $47,5 \mathrm{~cm}$, China, tweede kwart $18^{\circ}$ eeuw, Rijksmuseum, AK-RBK-15921

\section{Afbeelding 12}

Illustratie uit een editie van de Westelijke Kamer uit 1640. Uit: facsimile editie Museum fur Ostasiatische Kunst, Keulen duw van wat toen exclusief was, verbasterd terug te vinden in een exportalbum. De zwarte achtergrond is eveneens opmerkelijk. In beschrijvingen van Nederlandse collecties kwamen voor zover bekend eenmaal 'ingelijste Chinese prenten' voor 'met zwarte grond met gecouleurde Bloemen en Vogels'. ${ }^{33}$ Maar voor het overige zijn dergelijke albumbladen onbekend. Wellicht was het behangselpapier met florale motieven, met in het palet Oostindische inkt en zilver - één van de variëteiten die de VOC in 1786 bestelde - eveneens verwant. ${ }^{34}$ De combinatie van gekleurde bloemen en een zwarte achtergrond roept famille noire-porselein en lakwerk (vooral Europees imitatie lakwerk) in herinnering, maar beide waren geliefd aan het begin van de $18^{e}$ eeuw, niet in de jaren ' 70 en ' 80 van de eeuw. ${ }^{35}$ In Westerse prentkunst en toegepaste kunst komen in die tijd zwarte achtergronden juist wel in de mode. Classicistische voorstellingen, geïnspireerd door de opgravingen in Pompeï hebben soms een geheel zwarte achtergrond. ${ }^{36}$ Het is bekend dat modieuze prenten Kanton snel na publicatie bereikten en dat zal ook voor relatief goedkope, ingekleurde prenten met (eveneens ingekleurde) zwarte achtergronden hebben gegolden die in deze periode geliefd waren.

\section{Vorm en onderwerpskeuze: mogelijke Chinese voorbeelden}

De vraag die vervolgens voor ligt is of het maken van albums met mensen van allerhande statuur en bezigheid een zuiver Europees idee is, of dat het ook op een Chinese traditie aansluit. Hierboven besproken bladen (Yuanmingyuan en de fabeldieren in cartouches) bleken in een afgeleide vorm Chinese elementen te bevatten. De vraag is mede van belang omdat de introductie van een exportproduct eenvoudiger en succesvoller is, als het ook in de traditie past van het land waar het vervaardigd wordt. Vanwege de wens van verzamelaars als Royer en Van Braam, die het 'echte' China door middel van hun collectie wilden leren kennen, is het daarenboven interessant om te zien hoe Chinees de schilderingen waren waarop zij zich baseerden.

Kenmerkend voor deze albumbladen is dat de mensen steeds geïsoleerd, tegen een lege achtergrond zijn weergegeven. Zowel deze manier van afbeerdèn als 

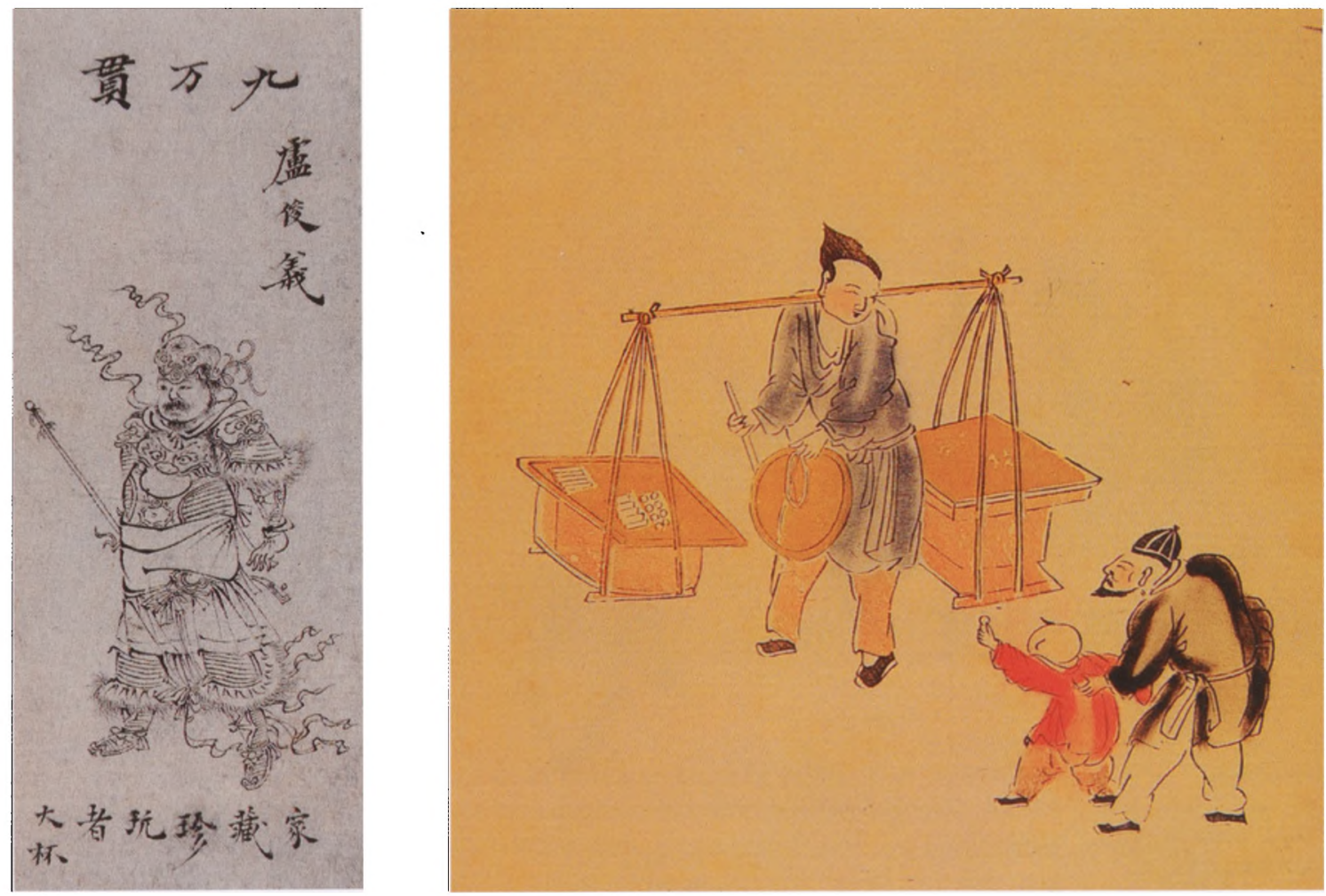

Afbeelding 13

Naar Chen Hongshou, kaartje voor een drinkspel met een Water Marginpersonage. Uit: cat. Christie's, zie noot 39

Afbeelding 14 Straathandelaar, gekleurde houtsnede,

$27,4 \times 28,3 \mathrm{~cm}$, Kupferstichkabinett, Dresden. Uit: Schatze Chinas, zie noot 46 de wens een groep afbeeldingen bijeen te brengen van verschillende bewoners van een bepaald gebied, wordt over het algemeen beschouwd als een Europees fenomeen. Het is vooral bekend uit Europese reisbeschrijvingen, waarin al in de $17^{e}$ eeuw dit soort illustraties werden opgenomen: van mensen uit de landen die werden beschreven, uit hun context, tegen een witte achtergrond, in karakteristieke kleding en liefst met een enkel typerend attribuut. ${ }^{37}$ Voor Chinezen zal de manier van afbeelden echter niet zo vreemd zijn geweest. In boekillustraties zijn afbeeldingen van figuren ten voeten uit tegen een lege achtergrond niet ongebruikelijk. ${ }^{38}$. Beroemd zijn de illustraties van Chen Hongshou (1598-1652) bij het boek Water Margin dat gaat over 108 bandieten uit de Noordelijke Song-tijd. ${ }^{39}$ Chen Hongshou heeft 40 van de hoofdpersonen afgebeeld - ten voeten uit, tegen een witte achtergrond en met een kleine inscriptie. Deze afbeeldingen waren invloedrijk en kenden een grote verspreiding. Er bestaan kaartjes met deze figuren die gebruikt werden bij drankspellen en de boeven van Chen Hongshou zijn door vele boekillustratoren nagevolgd en aangepast (afb. 13). ${ }^{40}$ De historische en mythologische figuren in Royers albums zijn, op een enkele uitzondering na nog niet geïdentificeerd. Zij zijn ongetwijfeld voor een groot deel gebaseerd op illustraties in historische romans. Op de eerste pagina's van die romans zijn vaak afbeeldingen van de hoofdpersonen afgedrukt (geïsoleerd weergegeven, tegen een witte achtergrond en voorzien van een inscriptie). Royer had zelf dergelijke geillustreerde romans uit China ontvangen en kan zich dus van de overeenkomst tussen de boekillustraties en zijn albums bewust zijn geweest. ${ }^{41}$ Vastgesteld kan worden dat Royers albums geen samenhangende reeksen van Chinezen bevatten. In één deel zijn een aantal Water Margin-figuren gecombineerd met een taoïstische Onsterfelijke, een aantal mensen uit historische romans en met een aantal beroepen ${ }^{3642}$. 


\section{Afbeelding 15 Iranier, schildering waarschijnlijk in Kanton vervaardigd en geba- seerd op Huangqing Zhigongtu ("Illustrated Tributaries of the Qing Empire'), voorheen Mottahedeh-collectie. Uit: Howard \& Ayers, zie noot 49}

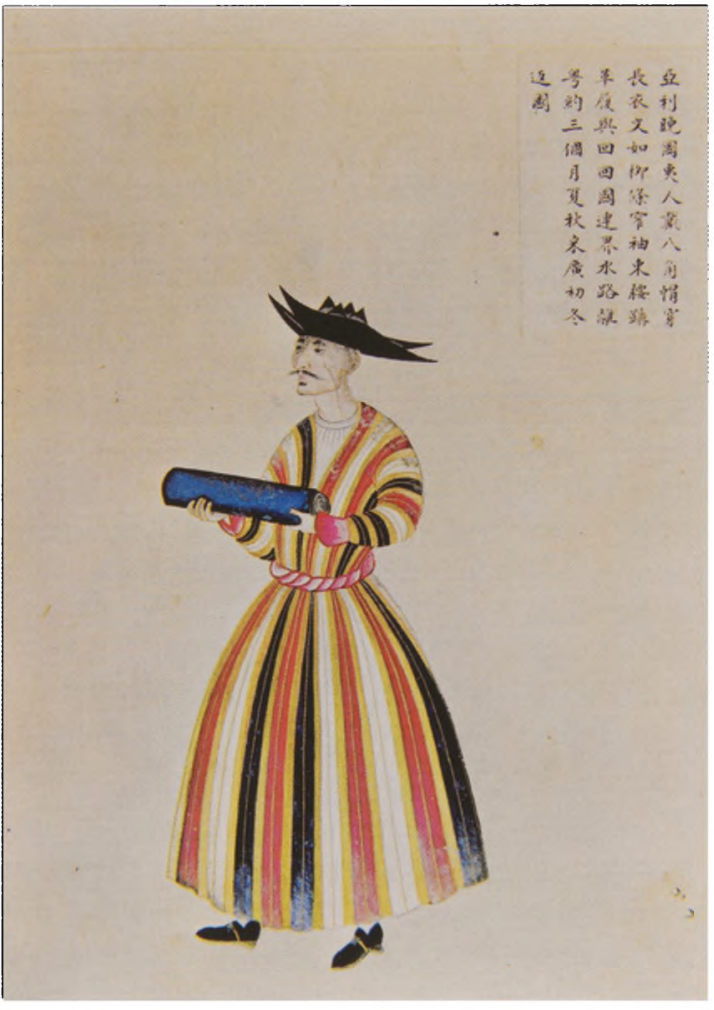

Het afbeelden van bestaande mensen, bij het uitoefenen van hun beroep of afkomstig uit verschillende gebieden, is iets anders dan het verwerken van boekillustraties. De keuze eenvoudige mensen bij de uitoefening van hun beroep af te beelden kent eveneens zowel Europese als Chinese voorbeelden. Clunas heeft gewezen op Europese verwante prenten. ${ }^{43}$ In China werden in opdracht van het hof series schilderingen gemaakt van de productie van zijde, thee en porselein. Vergelijkbaar met de $\mathbf{4 0}$ gezichten op Yuanmingyuan werden ook deze series pas bekend onder een breder publiek dankzij houtsnede-uitgaven en vervolgens werden de series zelfs aangepast aan Westerse wensen door toepassing van Europees perspectief, chiaroscuro en schaduw. ${ }^{44}$ Deze series wijken af doordat de mensen niet geïsoleerd tegen een witte achtergrond staan, maar het zijn wel eenvoudige mensen die bezig zijn met allerhande bezigheden. In 1780 kreeg Qianlong een album aangeboden met afbeeldingen van mensen, bezig met de verrichting van hun dagelijks leven. Voor het keizerlijke hof was het afbeelden van dit laag bij de grondse onderwerp wel degelijk van belang aangezien - in de woorden van Ming Wilson: 'men and women at work, however humble their occupation might be, represented a peaceful time.' ${ }^{45}$ Dit album is natuurlijk een zeer uitzonderlijk voorbeeld, maar Chinezen die op straat hun brood verdienen zijn ook het onderwerp van eenvoudige Chinese prenten uit het begin van de $18^{\mathrm{e}}$ eeuw (afb. 14). ${ }^{46}$ Blijkbaar vormden deze scènes ook vermakelijke plaatjes voor een groter Chinees publiek.

Het afbeelden van gewone mensen was dus niet onbekend in China. Dat geldt ook voor het vervaardigen van afbeeldingen van mensen uit andere gebieden, min of meer vanuit een etnografische belangstelling. Het bekendste voorbeeld is een set van vier rolschilderingen met afbeeldingen van $n_{\mathrm{via}}$ free access 
vertegenwoordigers uit alle tribuutbrengende landen en regio's, waarvan de productie in 1751 begon. ${ }^{47}$ Het zijn geïsoleerde figuren tegen een witte achtergrond en voorzien van een verklarende inscriptie. Deze rolschilderingen waren wederom weliswaar bestemd voor het keizerlijk hof, maar vergelijkbaar met de $\mathbf{4 0}$ gezichten op Yuanmingyuan en de series over de porselein-, theeen zijdeproductie, zorgde een uitgave in houtsneden voor een bredere verspreiding van deze afbeeldingen..$^{48}$ In de Mottahedeh-collectie bevond zich een groep schilderingen die gebaseerd zijn op deze tribuutbrengersrolschildering, maar die waarschijnlijk in een atelier in Kanton vervaardigd is (afb. 15). ${ }^{49}$ Andere afbeeldingen die vanuit diezelfde belangstelling gemaakt zijn, maar minder dicht bij het keizerlijke hof staan en dichter bij de ateliers die voor de Europese kopers werkten, zijn ook bekend. De plaatselijke Chinese autoriteiten lieten in de $18^{e}$ eeuw een visuele beschrijving maken van de inwoners van Macao in hun verschillende tenues. Het is waarschijnlijk door schilders uit Macao gemaakt. ${ }^{50}$

De indruk ontstaat dus dat de albums van Chinese mensen zijn ontstaan in de ateliers die aanvankelijk voor Europeanen vooral behangpapier vervaardigden, ateliers die rond 1760 volop in productie waren en die door de grote vraag werk boden aan een groot aantal Chinese beroepsschilders. De vraag naar albums met afbeeldingen van allerhande Chinezen past in de ontwikkeling van de etnografie en het verzamelen in het Europa van de tweede helft van de $18^{e}$ eeuw. De grote Chinese schildersateliers konden - zo lijkt het gemakkelijk aan die vraag tegemoetkomen, omdat de vorm en het onderwerp van die afbeeldingen voor de Chinese schilders niet geheel onbekend waren. De Chinese boekillustraties waren de gemakkelijkste bron, maar blijkbaar voldeden die afbeeldingen niet geheel aan de wens van de Europese kopers. Met behoud van de vorm van de boekillustraties werden nu ook gewone mensen op de albumbladen geschilderd. In Royers albums komen de Chinese literaire figuren nog veelvuldig voor en zijn ze vermengd met 'beroepen'. In de 'Puqua-sets' van circa 20 jaar later zijn uitsluitend de beroepen opgenomen, een enkele keer is nog sprake van aparte albums met historische figuren.

Waren deze exportalbums een geschikte bron voor China-vorsers als Royer en Van Braam? De mate waarin de schilderingen al dan niet in een Chinese context en traditie passen is voor die vraag niet van belang. De Chinese onderzoeker Jiang Yinghe heeft de afbeelding van vrouwen in laat $18^{\mathrm{e}}$-eeuwse exportschilderingen bestudeerd en vastgesteld dat de afbeeldingen waarheidsgetrouw zijn. ${ }^{51}$ Misschien kijken de Chinezen op de schilderingen iets meer tevreden dan men op grond van hun lot voor waar mag houden, als visuele bron was het precies wat Royer en Van Braam zochten.

Royer woonde in een ruim huis aan de Herengracht in Den Haag. Zijn grote en bekende Chinese collectie bevond zich op de eerste verdieping in een relatief kleine kamer. Hier was geen gelegenheid de voorwerpen, albums en rolschilderingen te bekijken, dat gebeurde in de naastgelegen bibliotheek. Wie in het laatste kwart van de $18^{\mathrm{e}}$ eeuw wilde weten hoe een Chinese literaat eruitzag, een concubine, of een schoenmaker had waarschijnlijk nergens in Europa zoveel kans hierop een antwoord te vinden als in deze bibliotheek in Den Haag. 
1. A.E. van Braam Houckgeest, Voyage de l'ambassade de la Compagnie des Indes Orientales Hollandaises, vers l'empereur de la China, dans les années 1794 \& 1795 , Philadelphia, 1797-1798. Voor informatie over Van Braam Houckeest zie J.P.W.A. van Braam Houckgeest, 'Leven en bedrijf van Andreas Everardus van Braam Houckgeest (1739-1801)', Bulletin van het Rijksmuseum 35/1 (1987), pp. 22-31 en J. van Campen, 'Chinese bestellingen van Andreas Everardus van Braam Houckgeest', Bulletin van het Rijksmuseum 53/1 (2005), pp. 18-41.

2. Over Royer: J. van Campen, De Haagse jurist Jean Theodore Royer (1737-1807) en zijn verzameling Chinese voorwerpen, Den Haag, 2000.

3. Inventaris van de verzameling opgesteld door R.P. van de Kasteele in 1816. Rijksarchief in Noord-Holland, Archief van het Rijksmuseum, inv.nr. 865.

4. Inventaris 1816, inv.nr. 364.

5. Met dank aan Klaas Ruitenbeek en John Finlay voor de identificatie van en informatie over de schilderingen. John Finlay verzorgde een concordantie tussen de bladen in het album van Royer en de originelen. Door een inscriptie in het handschrift van Carolus Wang (zie noot 12) kan Royers serie waarschijnlijk in het midden van de jaren ' 70 van de $18^{e}$ eeuw worden gedateerd.

6. Shen Zhou (1427-1509) en Wen Zhengming (1470-1559), vriendelijke mededeling Klaas Ruitenbeek.

7. Gepubliceerde series: Victoria and Albert Museum: M. Wilson en Liu Zhiwei (red.), Souvenir from Canton - Chinese Export Paintings from the Victoria and Albert Museum, Shanghai, 2003; Peabody Essex Museum, Salem (Mass.): Shijian Huang en W. Sargent (red.), Customs and conditions of Chinese City Streets in the $19^{\text {th }}$ Century - 360 Professions in China, Shanghai, 1999. Lee Sai Chong Jack, China trade painting: 1750s-1880s, Hongkong , 2005 (ongepubliceerde dissertatie Universiteit van Hongkong) voor de serie van 95 bladen in de Phillips Library (Salem, Mass.), p. 101 en appendix 5. Eén derde komt overeen met de Puqua/Mason schilderingen, de rest verschilt. Ik ben Rosalien van der Poel veel dank verschuldigd voor het ter beschikking stellen van een kopie van deze dissertatie. In de collectie Royer in Museum Volkenkunde bevinden zich twee series: 360-378 ( 288 bladen) en 360-377 met 320 bladen.

8. C. Clunas, Chinese Export Watercolours (Victoria and Albert Museum Far eastern Series), Londen, 1984.

9. Lee, Op.cit. (noot 7), p. 101.

10. Latere series zijn uitgebreider, zie een serie van 360 bladen in het Peabody Essex Museum uit circa 1830, in overeenstemming met het Chinese gezegde: 'Er zijn 360 beroepen en in elk beroep is er één de beste', Shijian Huang en Sargent, Op.cit. (noot 7), p. 13.

11. A Catalogue of a Capital, and truly valuable Assemblege of Chinese Drawings, Paintings, Natural and Artificial Curiosities, the property of A.E. van Braam, Esq., veiling 15 en 16 februari 1799, Christie's Londen, gepubliceerd als bijlage in J.J.L. Duyvendak, 'The last Dutch embassy to the Chinese court (1794-1795),', T'oung Pao 34 (1938), p. 116 en verder, dag 2 (p. 127) bij de nummers 48-50 worden 'Bonzes, Josses, Idols', en 'Ancient History of the Chinese' als onderwerp genoemd; De Indian Office Library verwierf in 1806 albums, onder andere met episodes uit toneelstukken en met boeddhistische heiligen, zie M. Archer, Company Drawings in the India Office Library, Londen, 1972, pp. 258-259.

12. Van Campen, Op.cit. (noot 2), pp. 77-79.

13. Chinese schilderingen in Schloss Ambras zijn een bekend voorbeeld, zie bijvoorbeeld F. Wappenschmidt, Chinesische Tapeten für Europa; vom Rollbild zur Bildtapete, Berlijn, 1989. In zijn onderzoek naar prenten aan de wand in de Nederlandse $17^{\mathrm{e}}$ eeuw stuitte Jan van de Waals af en toe op een Chinees of in ieder geval Aziatisch voorbeeld, zie J. van der Waals, Prenten in de Gouden Eeuw; van kunst tot kastpapier (tent.cat. Museum Boymans van Beuningen), Rotterdam, 2006, p. 234 (in 
een boedelbeschrijving van 1687: 'Sineesche print ofte schilderij'), op p. 236 (boedelbeschrijving 1695) 'een pauw met waterverf in Oost-Indiën konstig uijtgebeeld'.

14. Bij vroege vermeldingen van Chinese schilderingen aan boord van Engelse schepen, blijft het onduidelijk wat bedoeld kan zijn. Bijvoorbeeld: 'pictures 4 cases' in 1727, en in 1730400 losse vellen in een kist. Dit kunnen albumbladen zijn geweest, maar verdere informatie ontbreekt. Zie W. Sargent, 'Asia in Europe: Chinese paintings for the West', in: A. Jackson en A. Jaffer (red.), Encounters; the meeting of Asia and Europe 1500-1800 (tent.cat. V\&A Museum), Londen, 2004, pp. 272-281, aldaar p. 274.

15. R. van der Poel, Rijk palet - Chinese exportschilderkunst overzee (doctoraalscriptie Universiteit Leiden, Opleiding Kunstgeschiedenis), Leiden, 2008, p. 43.

16. Geciteerd in Lee, Op.cit. (noot 7), p. 60.

17. Sargent, Op.cit. (noot 14), p. 276, oorspronkelijk 34 bladen waarvan er 30 over zijn. De figuren zijn - in tegenstelling tot de albums door Puqua en van Royer - in een interieur dus in context afgebeeld. Een ander zeer interessant voorbeeld van een vroege verwerving van een Chinees album is de aankoop van 'een Boek Chineesse Theekenie' voor 235 gulden door Johan Hendrik van Wassenaer Obdam (1683-1745), een vooraanstaande Hollandse edelman, in 1728. Archief Huis Twickel, inv.nr. 543, met dank aan Menno Fitski.

18. Natural History Museum, Londen, een botanisch album uit de collectie van Charles de Robien, zie M. Wilson, 'Bridging China and the West - Chinese Export Paintings in the V\&A', in: Wilson en Liu Zhiwei, Op.cit. (noot 7), p. 11. In Drottningholm, Zweden, worden albums bewaard die voorkomen in de inventaris van 1777, zie A. Setterwal, The Chinese Pavillion at Drottningholm, Malmö, 1974, p. 322.

19. J. van Campen, Vervolg op: De Haagse furist Jean Theodore Royer (1737-1807) en zijn verzameling Chinese voorwerpen, Amsterdam, 2000, bijlage 10 (pp. 47-81). Wel worden behangsels geveild (in 1754 en 1786), incidenteel rollen (in 1778, 1796, 1801, 1806) en losse bladen (in 1754, 1778, 1786, 1794 (ingelijst)).

20. Catalogus van het considerable groote (...) magazyn, van (...) porcelynen (...) en fraaye rariteiten. Verkocht te Amsterdam op 24 augustus 1778 en volgende dagen, nr. 291 van de 'rariteiten' beginnende op p. 225.

21. Van Campen, Op.cit. (noot 2), pp. 151-154 en Van Campen, Op.cit. (noot 19), pp. 61-65.

22. Prof.dr. Michael North is een van de coördinatoren van de werkgroep 'The Reception of Netherlandish Art in Asia and its Impact on Asian and European Cultures' die aan de publicatie van een essaybundel werkt. Een ander voorbeeld is de beschrijving van het privévertrek van de VOC-dienaar Francois Hélène van Eymbeek op de factorij in Kanton (inventaris van overlijden in 1768). Hij bleek 46 kleine schilderijen aan de muur te hebben en zes kleine portretten van vrouwen geschilderd op glas. Zie C.J.A. Jörg, Porcelain and the Dutch China trade, Den Haag, 1982 , p. 63.

23. Wappenschmidt, Op.cit. (noot 13), pp. 28-29. Hier is ook al op gewezen door Clunas, Clunas 1984, Op.cit. (noot 8), p. 74.

24. Wappenschmidt schrijt dat Chinese prenten in groten getale werden meegenomen door Europese handelaren, zonder naar duidelijke bronnen te verwijzen, zie Wappenschmidt, Op.cit. (noot 13), p. 31. Ook prentwerk werd overigens als behang gebruikt.

25. Wappenschmidt, Op.cit. (noot 13), p. 18.

26. Wappenschmidt, Op.cit. (noot 13), pp. 18-19.

27. Wappenschmidt, Op.cit. (noot 13), pp. 80-82.

28. Wappenschmidt, Op.cit. (noot 13), p. 27-28.

29. Clunas, Op.cit. (noot 8), p. 77.

30. In de $19^{e}$ eeuw werd weer goedkoper Chinees papier gebruikt.

31. Het fraaiste voorbeeld is een editie van De Westelijke Kamer uit 1640 uitgegeven door Min Qiji, waarbij op intrigerende wijze 'beelden in beelden' zijn verwerkt, zie Wu Hung, The Double Screen; medium and representation in Chinese painting, Londen, 1996, pp. 237-258. R.E. Hegel, Reading Illustrated Fiction in Late Imperial 
China, Stanford, 1998, fig 4.26 toont een boekillustratie uit 1641 waar een 'droomwolk' met daarin figuren in een landschap vrijwel de hele pagina in beslag neemt.

32. N. Berliner, Yin Yu Tang; The architecture and daily life of a Chinese House, Boston etc., 2003, fig. 27 , foto uit de vroege $20^{e}$ eeuw.

33. Catalogue van een extra ordinair deftige en zindelyke inboedel (...) Alles nagelaaen door Steven Swart. Verkocht te Amsterdam, 15 april 1794 en volgende dagen, nrs. 510 van het hoofdstuk 'Schilderyen, Chineese en andere prenten in lysten met glaazen', p. 228 en verder.

34. Wappenschmidt, Op.cit. (noot 13), pp. 74-75.

35. Voor een voorbeeld van Europese imitatie van Aziatische lak, zie een kabinet in The Anglo-Dutch Garden in the Age of William and Mary / De Gouden Eeuw in de Hollandse Tuinkunst (Joumal of Garden History; an international quarterly 8/2-3 (april-sept. 1988)), nr. 169, pp. 312-313.

36. Zie bijvoorbeeld een snuifdoos uit 1782/83 in C. Truman, The Gilbert Collection of Gold Boxes (cat. Los Angeles County Museum), Los Angeles, 1991, nr. 32; voor prenten: V.I. Carlson en J.W. Ittman, Regency to Empire; French printmaking 17151814 (tent.cat. The Baltimore Museum of Art / The Minneapolis Institute of Arts), Baltimore, 1984, nr. 109; Populair waren in deze periode handgekleurde prenten met een zwarte achtergrond, bijvoorbeeld van Michelangelo Maestri.

37. D. Odell, 'Clothing customs and mercantilism; Dutch and Chinese ethnographies in the seventeenth century', Nederlands Kunsthistorisch Jaarboek 53 (2002), pp. 139159 , aldaar p. 158.

38. Zie bijvoorbeeld K. McLoughlin, 'Image and Appropriation; the formation of illustrated albums of Guanyin in $17^{\text {th }}$ Century print culture', in: $M$. Wilson en S. Pierson (red.), The Art of the Book in China (Colloquies on Art and Architecture in Asia 23), Londen, 2006, fig. 6 . Vaak zijn aan het begin van een boek de illustraties bijeengenomen en soms gaan zij dan een zelfstandig bestaan leiden.

39. Vriendelijke mededeling John Finlay, Parijs; voor afbeeldingen van de Water Margin-figuren zie bijvoorbeeld Fine Chinese Painting and Calligraphy (veilingcat. Christie's New York, 1 december 1993), nr. 208.

40. A. Burkus-Chasson, 'Visual Hermeneutics and the Act of Turning the Leaf; a genealogy of Liu Yuan's Lingyan ge', in: C. Brohaw en Kai-wing Chow (red.), Printing and Book Culture in Late Imperial China, Berkeley etc., 2005, pp. 371-416. Lingyan ge is de naam van een historisch gebouw waarin zich fresco's van 24 voorbeeldige staatslieden uit de Tang-dynastie bevonden. Liu Yuan publiceerde in 1669 een boek waarin deze staatsmannen paginagroot zijn afgebeeld - ten voeten uit, tegen een lege achtergrond. De manier waarop de figuren zijn weergegeven is voor een deel ontleend aan het werk van Chen Hongshou. Er bestaan latere navolgingen - in één geval als een geschilderde handrol, soms gebonden als concertina-album.

41. Sanguozhl, ('Het verslag van de Drie Rijken'), Sinologisch Instituut, 5754-2-I t/m 4, zie Van Campen, Op.cit. (noot 2), p. 271. Met dank aan Koos Kuiper, Sinologisch Instituut, Leiden. Losstaande figuren tegen een lege achtergrond, maar dan vaak ten halve lijve, waren in China ook bekend uit de portretkunst, niet alleen geschilderd, maar ook as boekillustratie, bijvoorbeeld in encyclopedieën. Li-ling Hsiao, The Eternal Present of the Past; illustration, theater, and reading in the Wanli period, 1573 1619, Leiden, 2007, pp. 244 en 285, illustraties uit 1569 en 1630.

42. Het opschrift op dit album (378b) is geheel overeenkomstig deze veelzijdigheid: ' 24 stuks afbeeldingen van mensfiguren van allerlei aard'. Met dank aan Ellen Uitzinger voor de vertaling.

43. Clunas, Op.cit. (noot 8), p. 45.

44. Zhou Chen schildert in 1516 al 'Beggars and Street Characters', zie Lee, Op.cit. (noot 7), p. 89, maar dit schijnt een geheel opzichzelfstaand kunstwerk. De in keizerlijke opdracht vervaardigde en later nagevolgde werken zijn Yuzhi Gengzhitu (over de landbouw en zijdeteelt) 1696; Taoye Tushuo (over de keramiekproductie) 1743, zie Sargent, Op.cit. (noot 14), p. 276.

45. Taiping Huanle Tu ('Pictures of Peace and Joy'), M. Wilson, 'As True as Photographs: 
Chinese paintings for the Western market', Orientations 31 (november 2000), pp. 8993, aldaar, p. 90.

46. Schätze Chinas aus Museen der DDR (tent.cat. Roemer- und Pelizaeus-Museum, Hildesheim), Mainz am Rhein, 1990, nrs. 97-99, volgens de inventaris waren ze in ieder geval in 1738 al in de collectie van August de Sterke, keurvorst van Saksen, Dresden. 'Gewone mensen' komen ook voor in schildershandboeken als The Mustard Seed Garden Manual of Painting, vooral bedoeld ter stoffering van landschappen. Wanneer mensen werkelijk het onderwerp van een schildering zijn, is er vrijwel altijd sprake van de uitbeelding van een scène uit een verhaal.

Zie S. McCausland en Ling Lizhong, Telling Images of China; narrative figure painting $15^{\text {th }}-20^{\text {th }}$ Century from the Shanghai Museum, Londen, 2010.

47. Huangqing Zhigongtu ('Illustrated Tributaries of the Qing Empire') afbeeldingen van mensen uit China en daarbuiten besteld in 1751 (klaar in 1790).

48. Odell, Op.cit. (noot 37), p. 147 en A. Jackson, 'Visual responses: depicting Europeans in East Asia', in Jackson en Jaffer, Op.cit. (noot 14), pp. 200-217, aldaar, p. 206. De 'Gazette of Guizhou province', in 1673 in opdracht van Kangxi vervaardigd, bevat afbeeldingen van bevolkingsgroepen die herkenbaar naar kleding zijn weergegeven, soms met een typerend object. Ook dit werk kreeg in commerciële kopieën en houtsneden zijn verspreiding. Zie L. Hostetler, 'Introduction: early modern ethnography in comparative historic perspective', in: D.M. Deal en L. Hostetler, The Art of Ethnography; a Chinese Miao Album', Seattle/Londen, 2006, pp. XVII-LXVII.

49. D. Howard en J. Ayers, China for the West; Chinese porcelain \& other decorative arts for export illustrated from the Mottahedeh Collection, Londen/New York, 1978, pp. 26-31.

50. Lee, Op.cit. (noot 7), p. 92, Aomen Jilue (A Recollection of Macao).

51. Jiang Yinghe, 'Female figures in Cantonese export painting', in: E. Groenendijk e.a. (red.), Canton and Nagasaki Compared 1730-1830; Dutch, Chinese, Japanese relations. Transactions (Intercontinenta No. 26), Leiden, 2009, pp. 79-90. 